Jurnal Akuntansi dan Bisnis: Jurnal Program studi Akuntansi, 5 (1) Mei 2019.

ISSN 2443-3071 (Print) ISSN 2503-0337 (Online). DOI: 10.31289/iab.v5i1.2455

JURNAL AKUNTANSI DAN BISNIS

Jurnal Program Studi Akuntansi

Available online http://ojs.uma.ac.id/index.php/jurnalakundanbisnis

\title{
PENGARUH PAJAK DAERAH DAN RETRIBUSI TERHADAP PENDAPATAN ASLI DAERAH KABUPATEN/KOTA DI SUMATERA UTARA
}

\author{
Puja Rizqy Ramadhan $a^{*}$ \\ ${ }^{a}$ Fakultas Sosial Sains, Universitas Pembangunan Panca Budi \\ Diterima April 2019; Disetujui April 2019; Dipublikasikan Mei 2019
}

\begin{abstract}
Abstrak
Penelitian ini bertujuan untuk mengetahui dan menganalisis pengaruh pajak daerah terhadap Pendapatan Asli Daerah (PAD) Kabupaten/Kota di Sumatera Utara; untuk mengetahui dan menganalisis pengaruh retribusi daerah terhadap Pendapatan Asli Daerah (PAD) Kabupaten/Kota di Sumatera Utara; dan untuk mengetahui dan menganalisis pengaruh pajak daerah dan retribusi daerah secara simultan terhadap Pendapatan Asli Daerah (PAD) di Kabupaten/Kota di Sumatera Utara. Populasi dalam penelitian ini adalah laporan keuangan yang telah diaudit di seluruh pemerintah Kabupaten/Kota di Sumatera Utara yang berjumlah 33 kabupaten/kota periode 2016, 2017, dan 2018. Sampel dipilih dengan menggunakan metode sensus. Data diolah menggunakan metode uji statistik regresi linear berganda. Hasil penelitian ini membuktikan bahwa pajak daerah berpengaruh terhadap Pendapatan Asli Daerah (PAD) Kabupaten/Kota di Sumatera Utara. Demikian juga halnya dengan retribusi daerah yang berpengaruh terhadap Pendapatan Asli Daerah (PAD) Kabupaten/Kota di Sumatera Utara. Adapun pajak daerah dan retribusi daerah berpengaruh secara simultan terhadap Pendapatan Asli Daerah (PAD) Kabupaten/Kota di Sumatera Utara.
\end{abstract}

Kata Kunci : Pendapatan Asli Daerah, Pajak Daerah, Retribusi Daerah

\begin{abstract}
This study is objected to find out and analyze the effect of local taxes on districts/cities regional revenue in North Sumatra; to find out and analyze the effect of regional retribution on districts/cities regional revenue in North Sumatra; and to find out and analyze the effect of regional taxes and regional retribution simultaneously on regional revenues in districts/cities in North Sumatra. The population in this study is audited financial statements in all districts/cities government in North Sumatra, which 33 districts/cities in the period 2016, 2017 and 2018. The samples were selected using the census method. Data is processed using multiple linear regression statistical test methods. The results of this study proved the local taxes affect the district/cities regional revenue in North Sumatra. Therefore, the regional retribution and regional have a simultaneous effect on on regional revenues in districts/cities regional revenue North Sumatera.
\end{abstract}

Keyword: Regional Revenue, Local Taxes, Local Retribution

How To Cite: Ramadhan, Puja Rizqy. (2019). Analisis Pengaruh Pajak Daerah dan Retribusi Daerah Terhadap Pedapatan Asli Daerah Kabupaten/Kota di Sumatera Utara. Jurnal Akuntansi dan Bisnis, 5 (1): 81-87

* email: pujarizqy@dosen.pancabudi.ac.id

\section{PENDAHULUAN}

Meningkatnya volume pembangunan dari tahun ke tahun dan ditambah dengan naiknya populasi penduduk dan kebutuhan hidup merupakan masalah dan beban 
pembangunan yang patut dicermati, upaya pemecahan masalah dan beban pembangunan tersebut menuntut peran pemerintah secara berkesinambungan. Meningkatnya peran pemerintah dalam pemecahan masalah tersebut berdampak pada meningkatnya dana yang dibutuhkan untuk membiayai pengeluaran-pengeluaran pemerintah di bidang pembangunan dan kemasyarakatan (Gomies dan Pattiasina, 2011).

Berdasarkan atas asas otonomi, maka potensi keuangan daerah akan dioptimalkan pemerintah daerah dalam rangka menopang keterselenggaraan urusan Pemda. Pendapatan Asli Daerah merupakan perwujudan dari penggalian sumber daya atau potensi yang dimiliki oleh suatu daerah.Dengan adanya otonomi daerah ini berarti pemerintah daerah dituntut untuk lebih mandiri, tak terkecuali juga mandiri dalam hal finansial (Zahari, 2008).

Dalam pelaksanaan otonomi di suatu daerah, maka darah tersebut diberikan kewenangan untuk mengelola keuangannya sendiri, termasuk dalam menggali potensi pendapatan daerahnya. Hal ini yang pada akhirnya diwujudkan dalam bentuk Pendapatan Asli Daerah (PAD). Pendapatan Asli Daerah (PAD) merupakan perwujudan dari penggalian sumber daya atau potensi yang dimiliki oleh suatu daerah. Pendapatan Asli Daerah (PAD) merupakan semua penerimaan daerah yang berasal dari sumber ekonomi asli daerah. Adapun sumber-sumber Pendapatan Asli Daerah terdiri dari pajak daerah retribusi daerah, hasil pengelolaan kekayaan yang dipisahkan, dan lain-lain PAD yang sah (Mardiasmo, 2002).

Pajak daerah dan retribusi daerah merupakan komponen penting dalam penerimaan PAD (Rosalina, 2014). Pajak daerah adalah iuran wajib yang dilakukan oleh orang pribadi atau badan kepada daerah tanpa imbalan langsung yang seimbang, yang dipaksakan berdasarkan perundang-undangan yang berlaku yang digunakan untuk membiayai penyelenggaraan pemerintah daerah dan pembangunan daerah (UU No. 34/2000). Adapun retribusi daerah merupakan pungutan daerah sebagai pembayaran atas jasa atau pemberian izin tertentu yang khusus disediakan dan/atau diberikan oleh pemerintah daerah untuk kepentingan orang pribadi atau badan (UU No. 34/2000).

Berbagai kebijakan nasional sebagaimana dimaksud membawa harapan besar bagi daerah untuk membangun daerahnya dengan menggali potensi daerahnya masing-masing sebagai sumber pendapatan daerah, khususnya pendapatan asli daerah. Harapan dari daerah tersebut merupakan hal yang wajar, karena diberikannya berbagai urusan pemerintahan sebagai urusan rumah tangganya dibarengi dengan muatan kewenangan untuk mengurus keuangannya secara otonom dalam membiayai penyelenggaraan otonomi, baik dalam menggali sumber-sumber keuangan, pemanfaatannya serta pertanggungjawabannya (Prakosa, K. B. 2004).

Walaupun ada kebijakan penyerahan tugas pemungutan beberapa jenis retribusi daerah kepada dinas atau instansi lain, Dinas Pendapatan tetap berkewajiban membina dan memonitor perkembangan terhadap segala usaha dibidang pendapatan atau penerimaan daerah, karena Dinas Pendapatan sebagai Koordinator Pendapatan Asli Daerah (PAD). Pada prinsipnya, semakin tinggi pencapaian penerimaan pajak daerah, maka semakin tinggi pula pencapaian penerimaan Pendapatan Asli Daerah (PAD) dalam struktur keuangan daerah. Demikian juga halnya dengan retribusi daerah, semakin tinggi pencapaian penerimaan retribusi daerah, maka semakin tinggi pula pencapaian penerimaan Pendapatan Asli Daerah (PAD) dalam struktur keuangan daerah (Anggraeni, 2012).

Realita empiris yang terjadi di Sumatera Utara mengindikasikan bahwa ada beberapa Kabupaten/Kota yang menunjukkan pola hubungan berbanding terbalik antara pajak daerah dan retribusi daerah terhadap PAD. Pada tahun 2013-2015 terdapat 
beberapa daerah yang mengalami penurunan pajak daerah dan retribusi daerah khususnya Kabupaten Nias, Kabupaten Simalungun, Kabupaten Tapanuli Tengah, Kabupaten Tapanuli Utara, Kabupaten Toba Samosir, Kota Binjai, Kota Pematang Siantar, Kota Tebing Tinggi, Kabupaten Humbang Hasundutan, Kabupaten Serdang Bedagai, Kabupaten Padang Lawas, Kabupaten Padang Lawas Utara, dan Kabupaten Labuhanbatu Utara. Daerah-daerah tersebut mengalami penurunan pajak daerah dan retribusi daerah, namun di sisi lain mengalami peningkatan PAD. Realita tersebut secara sekilas bertentangan dengan konsep Pendapatan Asli Daerah, dimana pajak daerah dan retribusi daerah memiliki arah hubungan yang positif terhadap PAD (Mardiasmo, 2002). Dengan kata lain, apabila pajak daerah dan retribusi daerah di suatu daerah mengalami peningkatan, maka seharusnya PAD juga mengalami peningkatan. Sebaliknya, apabila pajak daerah dan retribusi daerah di suatu daerah mengalami penurunan, maka seharusnya PAD juga mengalami penurunan.

Melihat kondisi tersebut, timbul adanya indikasi permasalahan yang terjadi di Sumatera Utara dalam hal pajak daerah dan retribusi daerah dengan kaitannya terhadap pencapaian PAD. Realita tersebut dapat menunjukkan isyarat kurang optimalnya kontribusi pajak daerah dan retribusi daerah berkontribusi terhadap PAD di Sumatera Utara, walaupun mengalami peningkatan di setiap tahunnya.Hal ini mengingat bahwa pajak daerah dan retribusi daerah merupakan komponen penting dalam hal kontribusinya terhadap PAD. Untuk itu, diperlukan adanya perhatian berkaitan dengan hal-hal yang dapat mempengaruhi pengelolaan PAD, pajak daerah, dan retribusi daerah di Kabupaten/Kota di Sumatera Utara.

\section{Pendapatan Asli Daerah}

Pendapatan asli daerah adalah penerimaan yang diperoleh dari sektor pajak daerah, retribusi daerah, hasil perusahaan milik daerah, hasil pengeloalaan kekayaan daerah yang dipisahkan, dan lain-lain pendapatan asli daerah yang sah (Mardiasmo,2011:1). Undang-Undang Nomor 33 Tahun 2004 tentang Perimbangan Keuangan Antara Pemerintah Pusat dan Pemerintah Daerah disebutkan bahwa sumber pendapatan daerah terdiri dari Pendapatan Asli Daerah, Bagi Hasil Pajak dan Bukan Pajak. Klasifikasi PAD yang terbaru berdasarkan Permendagri Nomor 13 Tahun 2006 terdiri atas: pajak daerah, retribusi daerah, hasil pengelolaan daerah yang dipisahkan, dan lain-lain pendapatan asli daerah yang sah. Adapun pengertian Pendapatan Asli Daerah (PAD) menurut Permendagri Nomor 13 Tahun 2006 pendapatan Asli Daerah (PAD) dipisahkan menjadi empat jenis pendapatan, yaitu: "pajak daerah, retribusi daerah, hasil perusahaan milik daerah, dan hasil pengelolaan kekayaan milik daerah yang dipisahkan, lain-lain PAD yang sah."

\section{Pajak Daerah}

Secara umum, pajak adalah pungutan dari masyarakat oleh negara (pemerintah) berdasarkan undang-undang yang bersifat dapat dipaksakan dan terutang oleh yang wajib membayarnya dengan tidak mendapat prestasi kembali (kontra prestasi/balas jasa) secara langsung, yang hasilnya digunakan untuk membiayai pengeluaran negara dalam penyelenggaraan pemerintahan dan pembangunan (Rahdina, 2008). Berdasarkan UU Nomor 34 Tahun 2000 tentang perubahan atas UU Nomor Tahun 1997 tentang pajak daerah dan retribusi daerah dalam Saragih (2003:61), yang dimaksud dengan pajak daerah adalah "iuran wajib yang dilakukan oleh orang pribadi dan badan kepada daerah tanpa imbalan langsung yang seimbang, yang dapat dipaksakan berdasarkan peraturan 
perundang-undangan yang berlaku, yang digunakan untuk membiayai penyelenggaraan pemerintah daerah dan pembangunan daerah."

\section{Retribusi Daerah}

Yang dimaksud dengan retribusi menurut Saragih (2003:65) adalah "pungutan daerah sebagai pembayaran atas jasa atau pemberian izin tertentu yang khusus disediakan dan atau diberikan oleh Pemda untuk kepentingan orang pribadi atau badan." Pemerintah pusat kembali mengeluarkan regulasi tentang Pajak Daerah dan Retribusi Daerah, melalui Undang-undang Nomor 28 Tahun 2009. Dengan UU ini dicabut UU Nomor 18 Tahun 1997, sebagaimana sudah diubah dengan UU Nomor 34 Tahun 2000. Berlakunya UU pajak dan retribusi daerah yang baru di satu sisi memberikan keuntungan daerah dengan adanya sumbersumber pendapatan baru, namun disisi lain ada beberapa sumber pendapatan asli daerah yang harus dihapus karena tidak boleh lagi dipungut oleh daerah, terutama berasal dari retribusi daerah.

\section{Pengaruh Pajak Daerah terhadap PAD}

Salah satu sumber pendapatan asli dari suatu daerah berasal dari pajak daerahnya. Oleh karena itu, maka dugaan yang dapat dimunculkan yaitu pajak daerah memiliki pengaruh terhadap PAD, dimana memiliki arah hubungan yang positif atau berbanding lurus.Dengan kata lain, semakin tinggi pajak daerah di suatu wilayah, maka akan semakin tinggi pula PAD wilayah tersebut. Sebaliknya, semakin rendah pajak daerah di suatu wilayah, maka semakin rendah pula PAD wilayah tersebut. Hal ini sejalan dengan penelitian yang dilakukan oleh Mariyanto (2015), dimana pajak daerah berpengatuh terhadap PAD. Begitu pula pada penelitian Anggraeni (2012) yang menyatakan bahwa pajak daerah berpengarih terhadap PAD. Penelitian Rosalina (2014) juga menyimpulkan hal yang serupa, bahwa pajak daerah berpengaruh terhadap PAD.

$\mathrm{H}_{1}$ : Ada pengaruh pajak daerah terhadap Pendapatan Asli Daerah Kabupaten/Kota di Sumatera Utara

\section{Pengaruh Retribusi Daerah terhadap PAD}

Retribusi daerah merupakan salah satu komponen yang berkontribusi terhadap PAD suatu daerah. Dengan demikian, dapat diambil dugaan sementara bahwa retribusi daerah berpengaruh terhadap PAD secara positif. Menurut Halim (2004), retribusi daerah yang semakin tinggi di suatu wilayah, akan mengakibatkan semakin tinggi pula PAD wilayah tersebut. Sebaliknya, semakin rendah retribusi daerah di suatu wilayah, maka semakin rendah pula PAD wilayah tersebut. Penelitian Mariyanto (2015) menyimpulkan bahwa retribusi daerah berpengaruh terhadap PAD. Anggreni (2012) dalam penelitiannya juga menyimpulkan bahwa retribusi daerah berpengaruh terhadap PAD. Hal yang sama juga berlaku pada penelitian Rosalina (2014), dimana retribusi daerah berpengaruh terhadap PAD.

$\mathrm{H}_{2}$ : Ada pengaruh retribusi daerah terhadap Pendapatan Asli Daerah Kabupaten/Kota di Sumatera Utara.

\section{Pengaruh Pajak Daerah dan Retribusi Daerah terhadap PAD}

Pendapatan Asli Daerah merupakan semua penerimaan daerah yang berasal dari sumber ekonomi asli daerah. Beberapa sumber PAD tersebut diantaranya adalah pajak daerah dan retribusi daerah. Oleh sebab itu, dugaan sementara yang dapat dimunculkan 
adalah bahwa pajak daerah dan retribusi daerah secara bersama-sama berpengaruh terhadap PAD secara positif, dimana semakin tinggi pajak daerah dan retribusi daerah di suatu wilayah, maka akan semakin tinggi pula PAD wilayah tersebut. Sebaliknya, semakin rendah pajak daerah dan retribusi daerah di suatu wilayah, maka semakin rendah pula PAD wilayah tersebut (Halim, 2004). Mariyanto (2015) dalam penelitiannya mengungkapkan bahwa pajak daerah dan retribusi daerah berpengaruh terhadap PAD. Anggreni (2012) dalam penelitiannya juga menyimpulkan bahwa pajak daerah dan retribusi daerah berpengaruh terhadap PAD. Demikian juga dalam penelitian Rosalina (2014), yang menyimpulkan bahwa pajak daerah dan retribusi daerah berpengaruh terhadap PAD.

$\mathrm{H}_{3}$ : Ada pengaruh pajak daerah dan retribusi daerah secara simultan terhadap Pendapatan Asli Daerah Kabupaten/Kota di Sumatera Utara.

\section{METODE PENELITIAN}

Dalam penelitian ini penulis menggunakan pendekatan penelitian asosiatif, dimana digunakan untuk memecahkan dan menjawab permasalahan yang dihadapi pada situasi sekarang, yang dilakukan dengan menempuh langkah-langkah pengumpulan klasifikasi dan analisis atau pengolahan data, membuat kesimpulan dan harapan dengan tujuan utama membuat gambaran tentang atau keadaaan secara objektif.

Untuk mengumpulkan data dan informasi yang diperlukan, maka penulis menggunakan metode studi dokumentasi: Dalam tahap metode ini merupakan kegiatan yang berhubungan dengan mengumpulkan dan mencari data-data pendukung yang berhubungan dengan data-data objek penelitian yang diperoleh dari instansi Dinas Pendapatan Daerah Provinsi Sumatera Utara dan dari website Direktorat Jenderal Perimbangan Keuangan Negara Republik Indonesia http://www.djpkn.go.id. Dalam menyelesaikan penelitian ini jenis data yang penulis kumpulkan untuk mendukung variabel yang diteliti adalah data kuantitatif, yaitu data keuangan daerah terutama berkaitan dengan PAD, pajak daerah, dan retribusi daerah.

Populasi dalam penelitian ini adalah laporan keuangan yang telah diaudit di seluruh pemerintah Kabupaten/Kota di Sumatera Utara yang berjumlah 33 kabupaten/kota. Adapun laporan keuangan yang hendak diteliti adalah laporan keuangan tahun 2013, 2014, dan 2015. Sampel adalah bagian dari populasi atau yang mewakili untuk diteliti. Teknik penarikan sampel menggunakan teknik sensus dimana seluruh populasi dijadikan sampel. Istilah lain sensus adalah sampel jenuh adalah, dimana semua anggota populasi dijadikan sampel. Teknik analisis data dalam penelitian ini yaitu berupa teknik analisis yang terdiri dari uji hipotesis terdiri dari uji parsial (uji t) dan uji simultan (Uji F).

\section{HASIL DAN PEMBAHASAN}

Berdasarkan Tabel 1.1 berikut dapat diketahui bahwa nilai signifikan variabel pajak daerah dan retribusi daerah lebih kecil dari 0,05. Pajak daerah menunjukkan nilai signifikansi 0,000 (Sig $=0,000<0,05$ ) sehingga secara parsial pajak daerah daerah berpengaruh signifikan terhadap Pendapatan Asli Daerah di Kabupaten/Kota di Sumatera Utara. Sementara itu, nilai signifikansi retribusi daerah adalah sebesar 0,000 ( $\mathrm{Sig}=0,000$ $<0,05)$, yang artinya retribusi daerah berpengaruh secara parsial terhadap PAD. Tabel 1.1 menunjukkan hasil uji parsial (uji t) yang dilakukan: 
Tabel 1 Uji Parsial

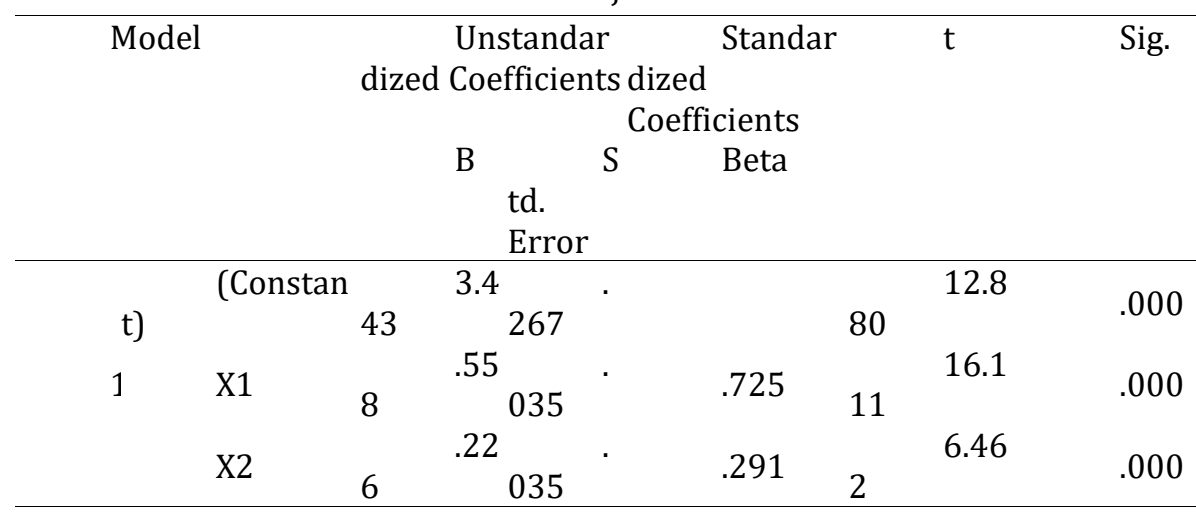

Tabel berikut menunjukkan hasil uji simultan (uji F) yang dilakukan:

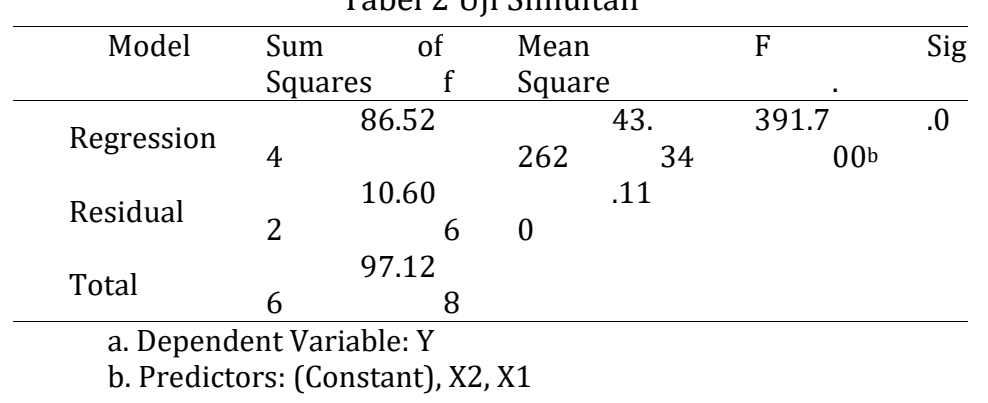

Berdasarkan Tabel 2 diketahui bahwa nilai signifikan 0,000 lebih kecil dari 0,05 sehingga dapat dikatakan bahwa secara simultan variabel pajak daerah dan retribusi daerah berpengaruh sigmifikan terhadap Pendapatan Asli Daerah di Kabupaten/Kota di Sumatera Utara.

\section{Pengaruh Pajak Daerah terhadap PAD}

Hasil pengujian pajak daerah terhadap PAD menggunakan uji $t$, dapat disimpulkan bahwa pajak daerah berpengaruh signifikan terhadap PAD. Hasil pengujian menerima hipotesis parsial. Secara teoritis, hal ini sesuai dengan konsep PAD bedasarkan Permendagri Nomor 13 Tahun 2006 yang menyatakan bahwa salah satu komponen PAD terdiri dari pajak daerah.

\section{Pengaruh Retribusi Daerah terhadap PAD}

Hasil pengujian retribusi daerah terhadap PAD menggunakan uji $t$, dapat disimpulkan bahwa pajak daerah berpengaruh signifikan terhadap PAD. Hasil pengujian menerima hipotesis parsial. Secara teoritis, hal ini sesuai dengan konsep PAD bedasarkan Permendagri Nomor 13 Tahun 2006 yang menyatakan bahwa salah satu komponen PAD terdiri dari retribusi daerah.

\section{Pengaruh Pajak Daerah dan Retribusi Daerah terhadap PAD}

Berdasarkan hasil uji statistik F yang dilakukan, diketahui bahwa variabel pajak daerah dan retribusi daerah berpengaruh secara simultan PAD Pemda Kab/Kota di Sumatera Utara. Mengacu kepada Permendagri Nomor 13 Tahun 2006, PAD terdiri atas: 
pajak daerah, retribusi daerah, hasil pengelolaan daerah yang dipisahkan, dan lain-lain pendapatan asli daerah yang sah. Hal ini berarti secara teoritis pajak daerah dan retribusi daerah merupakan variabel yang mempengaruhi PAD.

\section{SIMPULAN}

Dari hasil penelitian dan pengujian hipotesis yang telah dilakukan, dapat diambil beberapa kesimpulan bahwa pajak daerah berpengaruh terhadap Pendapatan Asli Daerah Pemerintah Kabupaten/Kota di Sumatera Utara. Untuk retribusi daerah berpengaruh terhadap Pendapatan Asli Daerah Pemerintah Kabupaten/Kota di Sumatera Utara. Dan yang terakhir pajak daerah dan retribusi berpengaruh secara simultan terhadap Pendapatan Asli Daerah Pemerintah Kabupaten/Kota di Sumatera Utara.

\section{DAFTAR PUSTAKA}

Abdul Halim (2004). Akuntansi Keuangan Daerah, Edisi Revisi Pertama. Jakarta: Salemba Empat.

Dini Anggraeni (2012). Kontribusi Pajak Daerah terhadap Pendapatan Asli Daerah Tahun 2010 dan 2011

(Studi Kasus Dinas Pendapatan Daerah Kabupaten Sleman), Universitas Negeri Yogyakarta.

Direktorat Jenderal Perimbangan Keuangan Negara. www.djpkn.go.id. Diakses 10 Agustus 2017

Erly Suandy (2008). Hukum Pajak, Jakarta: Salemba Empat

Gomes, Stevanus J. Dan Victor Pattiasina (2011). Analisis Kontribusi Pajak Daerah dan Retribusi Daerah Terhadap Pendapatan Asli Daerah di Kabupaten Maluku Tenggara. Aset. Vol. 13 No. 2

Imam Ghozali (2006). Aplikasi Analisis Multivariat Dengan Program SPSS. Edisi 4. Badan Penerbitan Universitas Diponegoro: Semarang.

J.P. Saragih (2003). Desentralisasi Fiskal dan Keuangan Daerah dalam Otonomi, Jakarta: Ghalia Indonesia.

Joko Mariyanto, Pajak Daerah dan Retribusi Daerah terhadap Pendapatan Asli Daerah (2015). Jurnal Akuntansi dan Sistem Teknologi Informasi Vol. 11 Maret 2015.

Kadjatmiko (2002). Dinamika Sumber Keuangan Bagi Daerah dalam Rangka Otonomi Daerah. Prosiding Workshop Internasional Implementasi Desentralisasi Fiskal sebagai Upaya Memberdayakan Daerah dalam Membiayai Pembangunan Daerah. Universitas Katolik Parahyangan. Bandung.

Lembaran Negara Republik Indonesia (2009). Undang-Undang Nomor 28 Tahun 2009 Tentang Perubahan Atas Undang-Undang Nomor 34 Tahun 2000 dan Undang-Undang Nomor 18 Tahun 1997 Tentang Pajak Daerah dan Retribusi Daerah.

Lembaran Negara Republik Indonesia (2004). Undang-Undang Nomor 32 Tahun 2004 Tentang Pemerintah Daerah.

Lembaran Negara Republik Indonesia. (2004). Undang-Undang Nomor 33 Tahun 2004 Tentang Perimbangan Keuangan Antara Pemerintah Pusat dan Pemerintah Daerah.

Mardiasmo (2002). Akuntansi Sektor Publik, Yogyakarta: Andi.

Marihot Pahala Siahaan (2013). Pajak Daerah dan Retribusi Daerah Berdasarkan Undang-Undang Nomor 28 Tahun 2009 Tentang Pajak Daerah dan Retribusi Daerah. Jakarta: Rajawali Pers.

Nasution, D. A. D. (2016). Analisis Faktor-faktor yang Mempengaruhi Implementasi SAP Berbasis Akrual dengan Komitmen SKPD sebagai Variabel Moderating pada Pemerintah Provinsi Sumatera Utara (Tesis). Universitas Sumatera Utara. Medan.

Nina Rosalina (2014). Kontribusi Pajak Daerah dan Retribusi Daerah terhadap Pendapatan Asli Daerah (PAD) Kabupaten dan Kota di Indonesia. Skripsi: UIN Syarif Hidayatullah.

Prakosa, K. B. (2004). Analisis pengaruh dana alokasi umum (DAU) dan pendapatan asli daerah (PAD) terhadap prediksi belanja daerah (studi empirik di wilayah propinsi Jawa Tengah dan DIY). Indonesian Journal of Accounting and Auditing, 8(2).

Rahdina. D.P. (2008). “Analisis Faktor-Faktor Penerimaan Pajak Daerah dan Retribusi Daerah di Kota Depok yang Mempengaruhi Otonomi Daerah", Skripsi, Institut Pertanian Bogor.

Zahari, M.S. (2008). Analisis Pendapatan Asli Daerah Kota Jambi Jurnal Akuntansi Volume 15, Nomor 1 